P.S.-A recent visit to Zelau shows that there is a much greater outcrop of andesitic and rhyolitic rocks in that area than I had previously suspected. There is also an outcrop of a fresh-looking granite which, in the field, resembles the granite exposed in the big creek on the Ex-Lands road, with which Dr. Falconer is familiar. If this granite is shown, on more exact examination than was possible on a flying visit, to be of the younger series, it will be the only case that I have observed of this granite forming a small isolated outcrop. So far I have failed to find any indication of marginal cooling.

I am informed by a mining engineer who knows the Zelau-BegindiLiuri-Kano country intimately, that outcrops of " younger" granite do occur near to Begindi and at Liuri-Kano. At the latter place they are associated with rhyolites apparently similar to those at the western end of the Ningi Hills. But this observer is, unfortunately, not familiar with the Sabon Garri - Ningi country. His work in the Liuri-Kano area has been thorough and systematic, and I hope that before long he will publish his results, as this country is extremely interesting from a petrological standpoint.

December 6, 1920.

G. W. W.

\title{
CARBONIFEROUS SPIRIFERINA.
}

SIR,-In Dr. F. J. North's recently published paper "On Syringothyris Winchell and certain Carboniferous Brachiopoda referred to Spiriferina, D'Orbigny" (Quart. Journ. Geol. Soc., vol. Ixxvi, pt. ii, November 30, 1920), there is a slight error with regard to the locality of the holotype of Spiriferina perplicata North (p. 219). This should be Treak Cliff, Castleton (as in "Explanation of Plates "), and not Peak's Hill. I take this opportunity to state that I have presented the holotype of this species ( $p l$. xiii, figs. $7 a-c$ ), as well as the figured specimen of Spiriferina insculpta (Ph.) (pl. xiii, fig. 11), to the Manchester Museum, where they will be more accessible than in private hands. It is unfortunate that the illustrations of Spiriferina perplicata do not do justice to the very distinct lamellose ornament and costation of this speciss.

\section{J. WILFRID JACKSON.}

Manchester Museum.

January $6,1921$. 